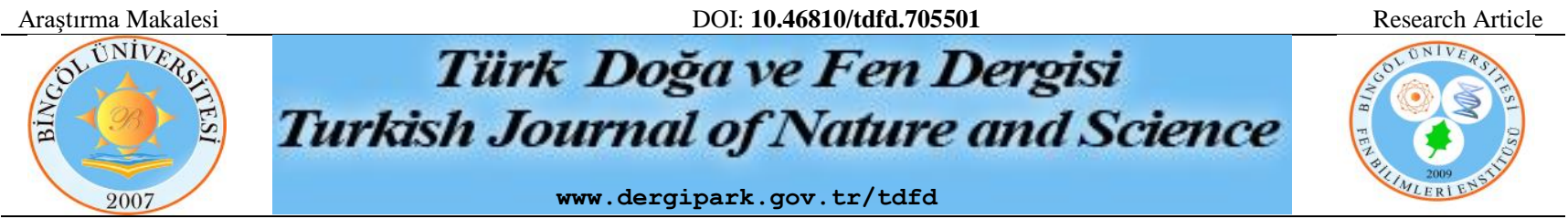

\title{
Ana Ürün Koşullarında Çift Sıralı Ekim Yöntemlerine Göre Oluşturulan Farklı Bitki Sıklığının, Değişik Büyüme Özelliğine Sahip Yerfıstığı (Arachis hypogaea L.) Çeşitlerinin Bazı Önemli Tarımsal ve Kalite Özellikleri Üzerine Etkileri
}

\author{
Halil BAKAL ${ }^{1 *}$ \\ ${ }^{1}$ Çukurova Üniversitesi, Ziraat Fakültesi, Tarla Bitkileri Bölümü, Adana, Türkiye \\ Ad SOYAD ORCID No: 0000-0002-9645-9291 \\ *Sorumlu yazar: hbakal@cu.edu.tr
}

(Alınış: 18.03.2020, Kabul: 27.05.2020, Online Yayınlanma: 18.06.2020)

\begin{abstract}
Anahtar
Kelimeler

Yerfistığ 1 ,

Çift sıralı

ekim,

Bitki sıklı̆̆ 1 ,

Meyve

verimi,

Tarımsal

özellik
\end{abstract}

Öz: $\mathrm{Bu}$ araştırma, Çukurova Bölgesi ana ürün koşullarında çift sıralı ekim yöntemlerine göre oluşturulan farklı bitki sıklığının, değişik büyüme özelliğine sahip yerfıstığı (Arachis hypogaea L.) çeşitlerinin bazı önemli tarımsal ve kalite özellikleri üzerine etkilerini belirlemek amacıyla yapılmıştır. Araştırmada farklı büyüme özelliğine sahip NC-7 (yatık) ve Halisbey (yarı-yatık) olmak üzere Virginia tipi iki farklı yerfıstığı çeşidi materyal olarak kullanılmıştır. Araştırmaya konu olan deneme; iki farklı çift sıralı ekim yöntemine (70-25-70 ve 80-25-80) ve dört farklı sıra üzeri mesafesine göre $(5,10,15$ ve $20 \mathrm{~cm})$ altı farklı bitki sıklığ $1(21.052,19.047,14.000,12.666,10.526$ ve $9.523 \mathrm{adet}_{\mathrm{da}^{-1}}$ ) oluşturulacak şekilde düzenlenmiştir. Araştırma; Çukurova Üniversitesi Ziraat Fakültesi, Tarla Bitkileri Bölümü deneme arazisinde 2017 ve 2018 yıllarında, bölünmüş parseller deneme desenine göre kurulmuş ve yürütülmüştür. Araştırmada kullanılan yerfıstı̆̆ı çeşitlerinde; bitki başına meyve sayısı, bitki başına meyve ağırlığı, 100 tohum ağırlığı, iç oranı, dekara meyve verimi, protein oranı ve yağ oranı gibi önemli özellikler incelenmiştir.Araştırma sonucunda, farklı bitki sıklığına göre denemeye alınan çeşitler arasında incelenen özellikler bakımından önemli farklılıklar saptanmıştır. Birim alandaki bitki sayısı artıkça, denemeye alınan her iki yerfıstığ çeşidinde de bitki başına meyve sayısı, bitki başına meyve ağırlığı, 100 tohum ağırlığı, iç oranı ve yağ oranı gibi özelliklere ait değerlerde önemli miktarda artışlar gözlenmiştir. Dekara meyve verimi değerleri, ekim yöntemine göre oluşturulan bitki sıklığına göre her iki yerfıstığı çeşidinde de farklı olmuş ve incelenen bu özellik bakımından da dekara en yüksek ortalama değer $\left(668,3 \mathrm{~kg} \mathrm{da}^{-1}\right)$ bitki sıklığ 12.666 adet da $^{-1}(80-25-80 \times 15$ cm ekim sıklığı) olarak yapılan ekimlerden elde edilmiştir.

\section{The Effect of Plant Density on Pod Yield and Some Agronomic Characteristics of Different Growth Type Peanut Varieties (Arachis hypogaea L.) Grown as a Twin Row Planting Pattern in Main Crop Growing Condition}

Keywords

Peanut,

Twin-row

planting

pattern,

Plant density,

Pod yield,

Agronomic

trait

\begin{abstract}
This study was conducted at the University of Cukurova, Faculty of Agriculture research area in 2017 and 2018. The aim of this study was to determine the effect of plant density on pod yield and some agronomic characteristics of different growth type peanut varieties (Arachis hypogaea L.) grown as a twin row planting pattern in main crop growing condition. In this research; two different growth type peanut varieties (Virginia market type) such as NC-7 (spread growth type) and Halisbey (semi-spread growth type) were used as a plant material. The twin-row planting pattern was arranged as 70-25-70 and $80-25-80 \mathrm{~cm}$, and six different plant densities such as 21.052 ,

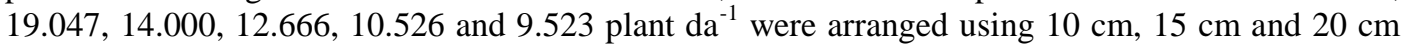
intra-row plant spacing. The experimental design was a split plot with three replications. Pod number and pod weight per plant, 100 seed weight, shelling percentage, oil and protein content and pod yield per decar characteristics of varieties were investigated. As a two-year average; pod number and weight per plant, 100 seed weight, shelling percentage and oil content values were increased when the plant density was decreased. The pod yield per decar was varied according to planting pattern and plant density in each variety. The highest pod yield was obtained when the plant density was 12.666 plant da $\mathrm{da}^{-1}(80-25-80 \times 15 \mathrm{~cm}$ planting pattern).
\end{abstract}




\section{GİRiş}

Yerfisttğı (Arachis hypogaea L.); tohumlarında \%45-55 oranında yağ, \%20-30 oranında protein ve \%18 oranında karbonhidrat ile önemli miktarda vitaminler ve madensel maddeler içermektedir. Yerfıstı̆̆ı tohumları genellikle yağ sanayinde ve çerez olarak kullanılmaktadır. Ayrıca, yerfistığı sapları yeşil ve kuru ot olarak hayvan beslenmesinde değerlendirilmektedir [1].

Yerfıstığı tohumları içerdiği yüksek orandaki (\%50-55) yağ nedeniyle soya, kolza ve çiğitten sonra dünyada en fazla üretimi yapılan dördüncü sıradaki yağlı tohum bitkisi olup, dünya bitkisel yağlı tohum ve ham yağ üretimi bakımından oldukça önemli bir yere sahiptir. 2018 yılı değerlerine göre dünya bitkisel yağlı tohum üretiminin \%7,3'ünü (41,9 milyon ton), bitkisel ham yăg üretiminin ise \%3.1'ini (5,95 milyon ton) yerfistığ 1 oluşturmaktadır [2]. 2019 yılı değerlerine göre ülkemizde toplamda 3,8 milyon ton yağli tohum üretilmekte, bunun ise $\% 4,5$ 'ini (169.328 ton) yerfistı ${ }_{1}$ oluşturmaktadır. Ülkemizde üretilen yerfistı̆̆ının tamamına yakını çerez olarak tüketilmektedir [3].

Yerfıstığında tarımında bitki yoğunluğu, yetiştirilecek olan çeşidin gelişme formuna göre değişmektedir. Yarı yatık gelişim formuna sahip çeşitler yatık çeşitlere göre daha sık ekilmelidir. Çünkü yatık gelişme formuna sahip çeşitler daha fazla yaşam alanına ihtiyaç duymaktadır. Ayrıca bitki yoğunluğu ekim zamanına göre de farklılıklar göstermektedir. İkinci ürün koşullarında vejetasyon süresi daha kısa olduğu için ana ürün koşullarında göre daha sık ekilmelidir. Son zamanlarda yerfıstığı tarımındaki mekanizasyonun gelişmesi ile söküm ve harman işlemleri tamamen makinalar ile yapılmaktadır. Özellikle söküm işleminin sağlıklı yapılabilmesi için sıra arası mesafesinin 70 veya $90 \mathrm{~cm}$, sıra üzeri mesafenin ise sik olması gerekmektedir. Yapılan araştırmalar göstermiştir ki; yerfıstığı tarımında, birim alandan elde edilecek verim üzerine etkili olan en önemli faktörlerin başında, bitki sıklığı gelmektedir [4]. Yapılan araştırmalar göstermiştir ki; dekardaki bitkisi sayısı azaldıkça, bitki başına elde edilen verim artmaktadır. Ancak dekardaki bitkisi sayısı azaldığından dolayı toplam verim azalmaktadır. Diğer yandan, dekardaki bitki sayısı arttıkça, bitki başına verim düşmekte, ancak dekardaki bitki sayısı arttığı için toplam verim artmaktadır. $\mathrm{Bu}$ artı̧̧ belirli bir bitki yoğunluğuna kadar artmaktadır, daha sonra ise düşmektedir [5]. Yerfıstı $\breve{g}_{1}$ veriminde ortaya çıkan bu değişim, çeşitlerin gelişme formuna ve bölgenin ekolojik özelliklerine göre değişmektedir. Lanier ve ark. [6], Kiniry ve ark. [7], Rasekh ve ark. [8], Konlan ve ark. [9] ve Onat ve ark. [10] tarafindan yapılan araştırmalarda, birim alandaki bitki sayısı arttıkça, verimde önemli artışların olduğu ortaya konmuştur.

Tarimo ve Blarney [11] yaptıkları bir çalışmada, birim alandan elde edilecek verim değerlerinin, çeşitlere ve ekim sıklığına göre değişim gösterdiğini, birim alandan elde edilen verimin, belirli bir bitki yoğunluğuna kadar artış gösterdiğini, daha sonra azalmaya başladığını bildirmişlerdir. Kadiroğlu [12], yerfistığı tarımında, çift sıralı ekim yönteminin uygulanması halinde, tek sıralı ekim yöntemine göre birim alandan daha yüksek verim alınabileceğini ortaya koymuştur. Kurt ve ark. [13], Virginia grubu yerfıstığı çeşidi ile ana ürün koşullarında yaptıkları bir çalışmada, en yüksek verimi, çift sıralı ekim yöntemine göre, dekardaki bitki sayısı 21.050 adet olduğunda elde etmişlerdir. Onat ve ark. [10], Halisbey yerfistığ 1 ile Çukurova bölgesi, ana ürün koşullarında yaptıkları bir çalışmada ise, birim alandaki bitki sayısı arttıkça, elde edilen meyve veriminde önemli artışların olduğunu bildirmişlerdir.

Ülkemizde, genellikle (\% 90) yatık ve yarı yatık arasında gelişim formuna sahip Virginia grubuna giren NC-7 yerfistığı çeşidi yetiştirilmektedir. Son yıllarda ise Çukurova Üniversitesi Zir. Fak. Tarla Bitkileri Bölümü tarafindan islah edilen ve NC-7 çeşidine göre birçok özelliği bakımından daha iyi olan yarı yatık büyüme formuna sahip Halisbey ve Sultan gibi çeşitlerin ekimi her geçen gün daha fazla ekilmeye başlamıştır. Yerfıstığı yetiştiriciliğinde ekimi yapılan çeşitlerin büyüme formuna bakmaksızın genelde standart bir ekim sıklı̆̆na göre ekim yapmaktadırlar. Bitki yoğunluğu bitkinin gelişim formuna göre farklılık gösterdiği için elde edilen ürünün kalitesi ve veriminde büyük kayıplar oluşabilmektedir [6]. Ayrıca, yanlış uygulanan bir ekim sıklığ bitkilerin büyüme ve gelişimini olumsuz etkilemektedir. Birim alandaki bitki sıklığı çeşidin gelişim formuna göre doğru belirlenmez ise hasat sırasında sorunların çıkmasına ve hasat kayıplarının artmasına neden olmaktadir [1].

Yukarıda yapılan açıklamalardan da görüleceği gibi, birim alandaki bitki sayısı ile verim arasında önemli bir ilişki bulunmaktadır. Bitki yoğunluğu arttıkça, elde edilen verim de artmaktadır. Normal ekim yöntemine göre, birim alandaki bitki sıklığı belirli bir sayıya kadar artırılabilmekte, ancak istenilen düzeye çıkarmak mümkün olmamaktadır. Oysa çift sıralı ekim yöntemine göre sıra üzeri mesafesini ayarlamak suretiyle, bitki sayısı istenilen düzeye çıkartılabilmektedir [13]. Yerfıstığı tarımında çift sıralı ekim yöntemi başta ABD olmak üzere, gelişmiş ülkelerde oldukça yaygın olarak uygulanmaktadır. Bu sayede verimde önemli artışlar sağlanmıştır [6,8,14-17]. Çift sıralı ekim yönteminde önemli olan konu, sıra arası ve sıra üzeri mesafesini ayarlamak suretiyle, çeşitlerin gelişme formuna göre birim alandaki optimum bitki sayısını sağlamaktır.

$\mathrm{Bu}$ çalışmanın amacı; yerfıstığı tarımının en yoğun olarak yapıldığı Çukurova bölgesinde ve ana ürün koşullarında, yatık ve yarı yatık gelişme formuna sahip yerfıstı̆̆ çeşitleri için, en yüksek verimin ve en kaliteli ürünün alınabileceği bitki sıklığını belirlemektir.

\section{MATERYAL VE METOT}

\subsection{Deneme Materyali}

$\mathrm{Bu}$ araştırma; Çukurova bölgesi ana ürün koşullarında çift sıralı ekim yöntemlerine göre oluşturulan farklı bitki yoğunluğunun, değişik büyüme özelliğine sahip yerfıstığ 1 (Arachis hypogaea L.) çeşitlerinin bazı önemli 
tarımsal ve kalite özellikleri üzerine etkilerini belirlemek amacıyla yapılmıștır. Araştırmada farklı büyüme özelliğine sahip NC-7 (yatık) ve Halisbey (yarı-yatık) olmak üzere Virginia grubu içerisinde yer alan iki farklı yerfıstığı çeşidi materyal olarak kullanılmıştır. NC-7 çeşidi A.B.D orijinli, Halisbey ise Ç. Ü. Ziraat Fakültesi Tarla Bitkileri Bölümü tarafından ıslah edilmiş olup, Türkiye orijinlidir. Araştırmaya konu olan denemeler; Ç.Ü. Ziraat Fakültesi, Tarla Bitkileri Bölümü deneme arazisinde 2017 ve 2018 yıllarında olmak üzere iki yıl süreyle yürütülmüştür.

\subsection{Deneme Yerinin İklim ve Toprak Özellikleri}

Denemenin yürütüldüğü Adana ilinde Akdeniz iklimi etkili olmaktadır. $\mathrm{Bu}$ nedenle kışları 1 lık ve yağışlı, yazları sıcak ve kurak geçmektedir. Deneme süresince Adana iline ait bazı iklim değerleri Tablo 1'de verilmiştir.

Tablo 1. Denemenin Kurulduğu Adana İline Ait Bazı İklim Değerleri (2017, 2018 ve Uzun yıllar (UY) iklim verileri

\begin{tabular}{|c|c|c|c|c|c|c|c|c|c|}
\hline \multirow{2}{*}{ Aylar } & \multicolumn{3}{|c|}{ Ortalama sıcaklık $\left({ }^{\circ} \mathrm{C}\right)$} & \multicolumn{3}{|c|}{ Toplam yağış (mm) } & \multicolumn{3}{|c|}{ Nispi nem (\%) } \\
\hline & 2017 & 2018 & U.Y. & 2017 & 2018 & U.Y. & 2017 & 2018 & U.Y. \\
\hline Nisan & 18,5 & 20,1 & 17,5 & 63,2 & 33,0 & 51,1 & 60,7 & 61,2 & 60,1 \\
\hline Mayıs & 21,8 & 24,4 & 21,7 & 44,4 & 25,6 & 47,1 & 68,8 & 62,8 & 63,2 \\
\hline Haziran & 26,2 & 26,4 & 25,6 & 19,4 & 27,0 & 20,5 & 69,1 & 70,2 & 70,2 \\
\hline Temmuz & 30,4 & 29,1 & 28,2 & 0,0 & 0,0 & 6,2 & 64,4 & 69,8 & 67,5 \\
\hline Ăgustos & 29,9 & 29,6 & 28,7 & 0,0 & 0,0 & 5,5 & 67,5 & 68,8 & 68,5 \\
\hline Eylül & 27,8 & 27,9 & 26,1 & 11,2 & 1,2 & 17,6 & 66,1 & 63,6 & 65,4 \\
\hline
\end{tabular}

Tablo 1'in incelenmesinden de görüleceği gibi, deneme süresince ölçülen ortama sıcaklık değerleri uzun yıllarda $17.5,{ }^{\circ} \mathrm{C}$ ile $28,7{ }^{\circ} \mathrm{C}$ arasında değişirken, 2017 yılında ortalama sicaklık değerleri $18,5-30,4^{\circ} \mathrm{C}$ ve 2018 yılında ise $20,1-29,6^{\circ} \mathrm{C}$ arasında değişim göstermiştir. Uzun yıllar verilerine göre yetiştirme sürecine ait toplam yağış miktarı 148,0 mm iken, 2017 y1lı verilerinde bu değer toplam 86,8 ve 2018 yılında ise 149,2 mm olarak gerçekleşmiştir. Her iki deneme yılında da yağışın yeterli olmaması nedeniyle, bitkilerin ihtiyaç duyduğu yağış sulama ile karşılanmıştır. Hava nispi nemi ise 2017 y1lında \% 60,7-69,1, 2018 y1linda ise \% 61,2-70,2 arasında değişim göstermiştir.

Denemenin kurulduğu topraklar Seyhan Nehrinin yan derelerinin getirdiği çok zengin alüvyonlardan oluşmuştur. Denemenin yapıldığı alana ait toprağın pH'sı her iki deneme yılında da 7,43-7,45 arasında olup, genellikle hafif alkali bir özellik göstermektedir. Toprağın $\mathrm{P}_{2} \mathrm{O}_{5}$ içeriği $2,8-3,0 \mathrm{~kg} \mathrm{da}{ }^{-1}, \mathrm{~K}_{2} \mathrm{O}$ içeriği ise $70,5-75,0 \mathrm{~kg} \mathrm{da}^{-1}$ olarak bulunmuştur. Yerfistığı tarımı için $\mathrm{K}_{2} \mathrm{O}$ içeriği yeterli düzeyde olup, $\mathrm{P}_{2} \mathrm{O}_{5}$ ihtiyacı gübreleme ile karşılanmıştır. Toprağın kireç içeriği \% 25,9-26,0 ve organik madde içeriği ise \%1,4-1,6 olarak belirlenmiştir. Denemeler her iki yılda da birbirine çok yakın yerlerde kurulduğu için, toprak yapısında yıllara göre önemli farklılıklar gözlenmemiştir.

\subsection{Araştırma Yöntemi ve Uygulama Tekniği}

Araştırma Ç.Ü. Ziraat Fakültesi Tarla Bitkileri Bölümü Deneme Alanında, bölünmüş parseller deneme desenine göre üç tekrarlamalı olarak kurulmuştur. Denemede çeşitler ana parsellere, bitki yoğunlukları ise alt parsellere yerleştirilerek ekim yapılmıştır. Ana ürün olarak ekim yapılan deneme arazisi pullukla sonbaharda 20-25 cm derinlikte sürülmüştür. Kışı bu şekilde geçiren toprak, ilkbaharda yüzlek olarak kültüvatör ile karıştırılmıştır. Ekim öncesi dekara $30 \mathrm{~kg}$ 18.46.0 DAP $\left(5,4 \mathrm{~kg} \mathrm{da}^{-1} \mathrm{~N}\right.$ ve $\left.13,8 \mathrm{~kg} \mathrm{da}^{-1} \mathrm{P}_{2} \mathrm{O}_{5}\right)$ gübresi uygulanarak diskaro ile toprağa karıștırılmıștır. Yabancı ot kontrolü için, etkili maddesi "Trifluralin" olan Traflen (150 cc da 1) isimli herbisit ekimden hemen önce toprağa uygulanarak karıştırılmıştır. Sonrasında deneme yerine iki defa tapan çekilerek deneme yeri ekime hazır hale getirilmiştir.

Ekim öncesi Şekil 1'de görüleceği gibi çift sıralı ekim yöntemine göre 5 metre uzunluğunda parseller oluşturulmuş ve sonra sıra üzeri mesafesi 10,15 ve 20 cm olacak şekilde ekimler yapılarak parsellerdeki gerekli bitki yoğunlukları (Tablo 2) sağlanmıştır. Ekim öncesi tohumlar, $100 \mathrm{~kg}$ tohuma $400 \mathrm{~g}$ ilaç düşecek şekilde $\% 80$ Thiram ile ilaçlanarak Nisan ayının ilk haftasında ekimler elle yapılmıştır. Yetişme süresi boyunca gerekli bakım işleri (sulama, çapalama ve ilaçlama) tekniğine uygun olarak zamanında yapılmıştır. Yetişme süresi içerisinde; üst gübre olarak birincisi çiçeklenme başlangıcında $\left(20 \mathrm{~kg} \mathrm{da}^{-1}\right)$ ve ikincisi de meyve oluşum başlangıcında $\left(20 \mathrm{~kg} \mathrm{da} \mathrm{da}^{-1}\right)$ olmak üzere iki defada toplamda $40 \mathrm{~kg} \mathrm{da}^{-1}$ Üre (\% $46 \mathrm{~N}$ ) uygulanmıştır. Hasat öncesi, parseldeki bitkilerden örnekler alınarak, kabuk soyma yöntemine göre olgunluk durumları belirlenmiş ve Eylül ayının ikinci haftasında bitkiler elle hasat edilmişlerdir.

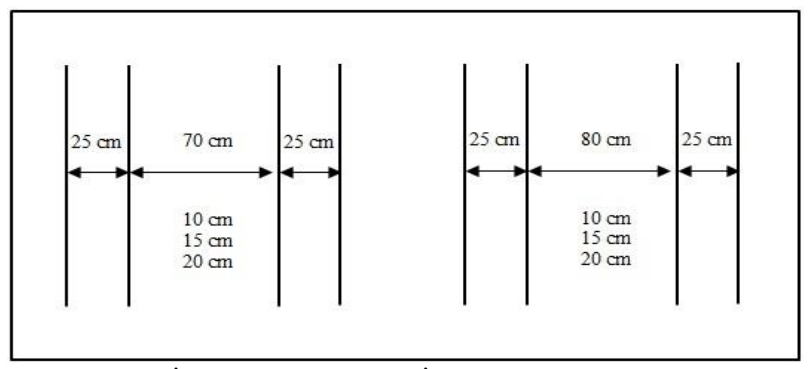

Şekil 1. Her İki Yerfıstığı Çeşidi İçin Uygulanan Çift Sıralı Ekim Yöntemi ve Sıra üzeri Uzaklığı 
Tablo 2. Çift sıralı ekim yöntemine göre oluşturulan farklı bitki yoğunlukları ve çeşitlere göre kullanılan tohum miktarları

\begin{tabular}{|c|c|c|c|c|}
\hline \multirow{2}{*}{$\begin{array}{c}\text { Ekim yöntemi } \\
\text { (çift sıralı) }\end{array}$} & $\begin{array}{c}\text { Sira üzeri } \\
\text { mesafesi (cm) }\end{array}$ & \multirow{2}{*}{$\begin{array}{c}\text { Bitki Yoğunluğu } \\
\text { (adet da }^{-1} \text { ) }\end{array}$} & \multicolumn{2}{|c|}{ Tohum miktarı (kg da ${ }^{-1}$ ) } \\
\cline { 4 - 5 } & & SULTAN & NC-7 \\
\hline $70-25-70$ & 10 & 21.052 & 24,2 & 22,7 \\
\hline $70-25-70$ & 15 & 14.000 & 16,1 & 15,3 \\
\hline $70-25-70$ & 20 & 10.526 & 12,1 & 11,4 \\
\hline $80-25-80$ & 10 & 19.047 & 21,9 & 20,6 \\
\hline $80-25-80$ & 15 & 12.666 & 14,6 & 13,7 \\
\hline $80-25-80$ & 20 & 9.523 & 10,9 & 10,3 \\
\hline
\end{tabular}

\section{4. İncelenen Özellikler ve Yöntemleri}

Meyveler hasat olgunluğuna ulaştığında, her parselden tesadüfen 20'şer bitki hasat edilmiş ve bu bitkiler üzerinde gerekli sayım ve ölçümler yapılmıştır. Bu çalışmada; bitki başına meyve sayısı (adet bitki ${ }^{-1}$ ), bitki başına meyve ağırlığı $\left(\mathrm{g}\right.$ bitki $\left.{ }^{-1}\right), 100$ tohum ağırlığı $(\mathrm{g})$, iç oranı $(\%)$, yağ oranı $(\%)$ ve protein oranı $(\%)$ gibi önemli bazı tarımsal ve kalite özellikleri incelenmiştir [18] meyve verimi $\left(\mathrm{kg} \mathrm{da}^{-1}\right)$ değerleri, her parselin orta iki sırasındaki bitkilerin tamamı hasat edilerek tartılmış ve parsel verimleri bulunmuştur. Daha sonra parsel verimleri esas alınarak dekara kabuklu meyve verimleri "kg da ${ }^{-1} "$ olarak hesaplanmıştır.

\section{BULGULAR VE TARTIŞMA}

\subsection{Bitki Başına Meyve Sayısı}

Ana ürün koşullarında denemeye alınan farklı büyüme özelliğine sahip yerfistı̆̆ sıklığına göre elde edilen iki yıllık bitki başına ortalama meyve sayısı ve meyve ağırlığı değerleri ile EGF (\%5)'e göre oluşan gruplar ve interaksiyon değerleri Tablo 3 'de verilmiştir.

Tablo 3. Ana ürün koşullarında denemeye alınan farklı büyüme özelliğine sahip yerfıstığı çeşitlerinin, farklı bitki yoğunluğuna göre elde edilen iki yıllık ortalama bitki başına meyve sayısı ve meyve ağırlığı değerleri ile EGF(\%5)'e göre oluşan gruplar

\begin{tabular}{|c|c|c|c|c|c|c|}
\hline \multirow{3}{*}{$\begin{array}{c}\text { Bitki } \\
\text { Yoğunluğu (B) } \\
\left(\text { adet } \mathbf{d a}^{-1}\right)\end{array}$} & \multicolumn{3}{|c|}{$\begin{array}{c}\text { Bitki başına meyve sayısı } \\
\text { (adet bitki }^{-1} \text { ) }\end{array}$} & \multicolumn{3}{|c|}{$\begin{array}{c}\text { Bitki başına meyve ağırlığı } \\
\left(\text { g bitki }^{-1}\right)\end{array}$} \\
\hline & \multicolumn{2}{|c|}{ Çeşitler (A) } & \multirow{2}{*}{$\begin{array}{l}\text { Ortalama } \\
\text { (B) }\end{array}$} & \multicolumn{2}{|c|}{ Çeşitler (A) } & \multirow{2}{*}{ Ortalama (B) } \\
\hline & SULTAN & NC-7 & & SULTAN & NC-7 & \\
\hline 21.052 & $15,4 \mathrm{~g}$ & $9,9 \mathrm{~h}$ & $12,7 \mathrm{~F}$ & $29,9 \mathrm{~h}$ & 21,31 & $25.6 \mathrm{~F}$ \\
\hline 19.047 & $18,6 \mathrm{f}$ & $15,7 \mathrm{~g}$ & $17,1 \mathrm{E}$ & $37,6 \mathrm{f}$ & $30,7 \mathrm{gh}$ & $34.2 \mathrm{E}$ \\
\hline 14.000 & $23,0 \mathrm{~d}$ & $16,0 \mathrm{~g}$ & $19,5 \mathrm{D}$ & $39,7 \mathrm{e}$ & $31,1 \mathrm{~g}$ & $35.4 \mathrm{D}$ \\
\hline 12.666 & $25,8 \mathrm{~b}$ & $19,6 \mathrm{e}$ & $22,7 \mathrm{C}$ & $49,5 \mathrm{c}$ & $40,9 \mathrm{~d}$ & $45.2 \mathrm{C}$ \\
\hline 10.526 & $26,1 \mathrm{~b}$ & $22,4 \mathrm{~d}$ & $24,2 \mathrm{~B}$ & $50,9 \mathrm{~b}$ & $41,5 \mathrm{~d}$ & $46.2 \mathrm{~B}$ \\
\hline 9.523 & $31,3 \mathrm{a}$ & $23,9 \mathrm{c}$ & $27,6 \mathrm{~A}$ & $61,2 \mathrm{a}$ & $49,2 \mathrm{c}$ & $55.2 \mathrm{~A}$ \\
\hline Ortalama (A) & $23,3 \mathrm{~A}$ & $17,9 \mathrm{~B}$ & - & $44,8 \mathrm{~A}$ & $35,8 \mathrm{~B}$ & - \\
\hline EGF (\%5) Değerleri & \multicolumn{3}{|c|}{$\begin{array}{c}\operatorname{EGF}\left(\% 5_{\mathrm{A}}\right): 0,95 ; \mathrm{EGF}\left(\% 5_{\mathrm{B}}\right): 0,47 \\
\operatorname{EGF}\left(\% 5_{\mathrm{AxB}}\right): 0.67\end{array}$} & \multicolumn{3}{|c|}{$\begin{array}{c}\operatorname{EGF}\left(\% 5_{\mathrm{A}}\right): 1.01 ; \operatorname{EGF}\left(\% 5_{\mathrm{B}}\right): 0.77 \\
\operatorname{EGF}\left(\% 5_{\mathrm{AxB}}\right): 1.09\end{array}$} \\
\hline
\end{tabular}

Tablo 3'ün incelenmesinden de görüleceği gibi bitki başına meyve sayısı bakımından, farklı bitki sıklığına göre denemeye alınan yerfıstığı çeşitleri arasında istatistiksel olarak önemli farklılıklar saptanmıştır (Tablo 3). İki yıllık ortalama değerlere göre bitki başına meyve sayıs1 Sultan çeşidinde 23,3 adet bitki ${ }^{-1}$ iken, NC-7 çeşidinde 17,9 adet bitki ${ }^{-1}$ olarak saptanmıştır. Bitki başına meyve sayısı Sultan çeşidinde daha yüksek bulunmuştur. Bitki başına meyve sayısı bakımından çeşitler arasında meydana gelen farklılık, çeşitlerin farklı genetik yapıya sahip olmalarından kaynaklanmaktadır $[21,9]$.

Bitki başına en yüksek meyve sayısı değeri 80-25-80 x $20 \mathrm{~cm}$ çift sıralı ekim yöntemine göre oluşturulan, 9.523 adet da $^{-1}$ bitki sıklığ bulunan parsellerden elde edilmiştir (Tablo 3). Meyve sayısı değerleri, çeşitlere ve bitki sıklığına göre farklılık göstermiştir. Bitki başına meyve sayısı değeri en yüksek (31,3 adet bitki $\left.{ }^{-1}\right) 9.523$ adet da $^{-1}$ bitki yoğunluğu bulunan Sultan çeşidinden, en düşük $\left(9,9\right.$ adet bitki $\left.{ }^{-1}\right)$ ise 21.052 adet $\mathrm{da}^{-1}$ bitki yoğunluğu bulunan NC-7 çeşidinden elde edilmiştir. Ekim sıklığı azaldıkça, bitki başına meyve sayısının artmasının nedeni, birim alandaki bitki sayısı azaldıkça, bitki başına düşen yaşam alanının artmasından ileri gelmektedir. Bu çalışmada elde edilen bulgular, benzer konularda çalışmalar yapan araştırıcıların bulguları ile uyum içerisinde olmuştur [5,9,10,13,19-23].

\subsection{Bitki Başına Meyve Ağırlığı}

İki yıllık ortalama değerlere göre bitki başına meyve ağırlığı değerleri bakımından çeşitler ve ekim sıklıkları arasındaki farklılıklar istatistiksel olarak önemli bulunmuştur. Çift sıralı ekim yöntemine göre düzenlenen farklı bitki sıklığına göre oluşturulan parsellere yapılan ekimlerde, bitki başına ortalama meyve ağırlığı değeri Sultan çeşidinde 44,8 $\mathrm{g}_{\text {bitki }}{ }^{-1}$ iken, NC-7 çeşidinde 35,8 $\mathrm{g}$ bitki $^{-1}$ olmuştur. Bitki başına elde edilen meyve ağırlığının çeşitlere göre farklı olması, çeşitlere göre bitki başına meyve sayısının ve 100- tohum ağırlığının farklı olmasından kaynaklanmıştır.

İki yıllık ortalama değerlere göre bitki başına ortalama meyve ağırlığı değerleri, bitki sıklığına göre 25,6-55,2 g bitki $^{-1}$ arasında değişim göstermiştir. Birim alandaki bitki 
sayısı azaldıkça, bitki başına elde edilen ortalama meyve ağırlığı değerlerinde önemli miktarda artışlar saptanmıştır. İki yıllık ortalama değerlere göre bitki başına en yüksek ortalama meyve ağırlığı değeri $(61,2 \mathrm{~g}$ bitki $^{-1}$ ) Sultan çeşidinden ve 80-25-80 x $20 \mathrm{~cm}$ ekim yöntemine göre oluşturulan 9.523 adet $\mathrm{da}^{-1}$ bitki yoğunluğunun bulunduğu parsellerden elde edilmiştir. Bitki başına meyve ağırlığının, bitki yoğunluğu arttıkça azalmasının nedeni, bitki başına yaşam alanının azalması ile oluşan meyve sayısının azalmasından kaynaklanmaktadır. Elde edilen bulgular; Ahmad ve ark. [21], Awal ve Aktar [22], Kurt ve ark. [13], Onat ve ark. [10], Zhao ve ark. [5] ve Yousif ve Hussain [23]'in bulguları ile de desteklenmektedir.

\subsection{Tohum Ağırlığı}

Ana ürün koşullarında denemeye alınan farklı büyüme özelliğine sahip yerfıstığı çeşitlerinden, farklı bitki yoğunluğuna göre elde edilen bitki başına iki yılllk ortalama 100 tohum ağırlığı ve iç oranı değerleri ile EGF(\%5)'e göre oluşan gruplar ve interaksiyon değerleri Tablo 4'de verilmiştir.

Tablo 4'ün incelenmesinden de görüleceği gibi, 100 tohum ağırlığı değerleri bakımından, çeşitler ve bitki sıklıkları arasında istatistiksel olarak önemli düzeyde farklılıklar saptanmıştır. Farklı ekim sıklıklarına göre denemeye alınan çeşitlerin ortalama 100 tohum ağırlığ değerleri Sultan çeşidinde 131,4 g iken, bu değer NC-7 çeşidinde $113,7 \mathrm{~g}$ olmuştur. Sultan çeşidinde 100 tohum ağırlığının daha yüksek olması, çeşit özelliğinden ileri gelmektedir [24]. NC-7 çeşidi demir eksikliğine karşı çok hassas olduğu için, tohumlarını yeteri kadar geliştirememektedir.

Tablo 4. Ana ürün koşullarında denemeye alınan farklı büyüme özelliğine sahip yerfıstığı çeşitlerinin, farklı bitki yoğunluğuna göre elde edilen iki yıllık ortalama 100 tohum ağırlı̆̆ı ve iç oranı değerleri ile EGF(\%5)'e göre oluşan gruplar

\begin{tabular}{|c|c|c|c|c|c|c|}
\hline \multirow{3}{*}{$\begin{array}{c}\text { Bitki } \\
\text { Yoğunluğu (B) } \\
\left(\text { adet } \text { da }^{-1}\right)\end{array}$} & \multicolumn{3}{|c|}{100 Tohum Ağırlığı (g) } & \multicolumn{3}{|c|}{ İç Oranı (\%) } \\
\hline & \multicolumn{2}{|c|}{ Çeşitler (A) } & \multirow{2}{*}{$\begin{array}{l}\text { Ortalama } \\
\text { (B) }\end{array}$} & \multicolumn{2}{|c|}{ Çeşitler (A) } & \multirow{2}{*}{$\begin{array}{l}\text { Ortalama } \\
\text { (B) }\end{array}$} \\
\hline & SULTAN & NC-7 & & SULTAN & NC-7 & \\
\hline 21.052 & $125,8 \mathrm{e}$ & $108,1 \mathrm{j}$ & $117,0 \mathrm{E}$ & 64,131 & $69,57 \mathrm{e}$ & $66,85 \mathrm{E}$ \\
\hline 19.047 & $128,8 \mathrm{~d}$ & 109,81 & $119,3 \mathrm{D}$ & $64,69 \mathrm{~h}$ & $69,61 \mathrm{de}$ & $67,15 \mathrm{D}$ \\
\hline 14.000 & $132,4 \mathrm{c}$ & $112,1 \mathrm{~h}$ & $122,3 \mathrm{C}$ & $64,84 \mathrm{~h}$ & $69,85 \mathrm{~cd}$ & $67,34 \mathrm{C}$ \\
\hline 12.666 & $133,0 \mathrm{bc}$ & $114,6 \mathrm{~g}$ & $123,8 \mathrm{~B}$ & $65,23 \mathrm{~g}$ & $70,06 \mathrm{bc}$ & $67,65 \mathrm{~B}$ \\
\hline 10.526 & $133,4 \mathrm{~b}$ & $115,3 \mathrm{~g}$ & $124,3 \mathrm{~B}$ & $65,41 \mathrm{~g}$ & $70,17 \mathrm{ab}$ & $67,79 \mathrm{~B}$ \\
\hline 9.523 & $134,8 \mathrm{a}$ & $122,0 \mathrm{f}$ & $128,4 \mathrm{~A}$ & $65,68 \mathrm{f}$ & $70,40 \mathrm{a}$ & $68,04 \mathrm{~A}$ \\
\hline Ortalama (A) & $131,4 \mathrm{~A}$ & $113,7 \mathrm{~B}$ & - & $65,00 \mathrm{~B}$ & $69,94 \mathrm{~A}$ & - \\
\hline EGF (\%5) Değerleri & \multicolumn{3}{|c|}{$\begin{array}{c}\mathrm{EGF}\left(\% 5_{\mathrm{A}}\right): 0,52 ; \mathrm{EGF}\left(\% 5_{\mathrm{B}}\right): 0.56 \\
\mathrm{EGF}\left(\% 5_{\mathrm{AxB}}\right): 0.79\end{array}$} & \multicolumn{3}{|c|}{$\begin{array}{c}\operatorname{EGF}\left(\% 5_{\mathrm{A}}\right): 2,83 ; \quad \operatorname{EGF}\left(\% 5_{\mathrm{B}}\right): 0,19 \\
\operatorname{EGF}\left(\% 5_{\mathrm{AxB}}\right): 0,26\end{array}$} \\
\hline
\end{tabular}

Denemeye alınan çeşitlere ait iki yıllık ortalama 100 tohum ağırlığı değerleri, bitki sıklığına göre Sultan çeşidinde 125,8-134,8 g arasında ve NC-7 çeşidinde ise 108,2-122,0 g arasında değişim göstermiştir. Ekim sıklığına göre meydana gelen bu artışlar, çeşitlere göre farklı düzeylerde olmuştur. Birim alandaki bitki sayısı azaldıkça, her iki yerfıstığı çeşidinde de ortalama 100 tohum ağırlığ 1 değerleri 117,0 g'dan, 128,4 g'a kadar artış göstermişlerdir (Tablo 4). Birim alandaki bitki sayısı azaldıkça, bitki başına düşen yaşam alanı genişleyeceği için, bitkiler daha fazla kuru madde biriktirecekler ve bu nedenle de tohumlar daha iyi gelişecek ve 100 tohum ağırlığı daha fazla olacaktır. Bu çalışmada, 100 tohum ağırlığ 1 değerleri bakımından elde edilen bulgular, benzer konularda araştırmalar yapan araştırıcıların bulguları ile de desteklenmektedir [25, 11, $13,10,5,23]$.

\section{4. İç Oranı}

Tablo 4'ün incelenmesinden de görüleceği gibi denemeye alınan yerfıstığ ortalama değerlere göre birbirlerinden önemli derecede farklı bulunmuştur. İki yıllık ortalama değerlere göre iç oranı Sultan çeşidinde \%65,00 ve NC-7 çeşidinde ise \%69,94 olarak hesaplanmıştır. Sultan çeşidinde meyveler daha iri ve kabukları daha kalın olduğu için, iç oranı (randımanı) daha düşük olmuştur. $\mathrm{Bu}$ durum çeşitlerin genetik yapılarına göre değişmektedir [24].

Çift sıralı ekim yöntemine göre oluşturulan farklı bitki yoğunluklarına göre denemeye alınan yerfistığı çeşitlerinin iç oranı değerleri birbirlerinden önemli derecede farklılıklar göstermiştir. İki yıllık ortalama değerlere göre Sultan çeşidine ait iç oranı değerleri, farklı bitki sıklığına göre \%64,13-65,68 arasında, NC-7 çeşidinde ise \%69,57-70,40 arasında değişim göstermiştir (Tablo 4). Denemeye alınan iki çeşidin ortalamasına göre, iç oranı değerleri bakımından bitki yoğunlukları arasındaki farklılıklar istatistiki olarak önemli olmasına rağmen, birim alandaki bitki yoğunluğu değerleri arasında çok büyük farklılıklar gözlenmemiştir. Birim alandaki bitki yoğunluğu azaldıkça, çeşitlere ait iç oranı değerlerinde önemli oranda artışlar saptanmıştır. İç oranı bakımından elde edilen değerler; Arığlu ve Arığlu [26], Rasekh ve ark. [8], Konlan ve ark. [9], Kurt ve ark. [13], Onat ve ark. [10]'nın bulguları ile de desteklenmektedir.

\subsection{Yağ Oranı}

Ana ürün koşullarında denemeye alınan farklı büyüme özelliğine sahip yerfıstığı çeşitlerinden, farklı bitki sıklıklarına göre elde edilen iki yıllık ortalama yă ve 
protein oranı değerleri ile $\mathrm{EGF}(\% 5)$ 'e göre oluşan gruplar ve interaksiyon değerleri Tablo 5'de verilmiştir.

Tablo 5'in incelenmesinden de görüleceğgi gibi denemeye alınan yerfıstığ oranı değerleri Sultan çeşidinde \%46,51 iken, NC-7 çeşidinde \%44,51 olarak bulunmuştur (Tablo 5). Yağ oranı değerleri bakımından çeşitler arasındaki fark, istatistiksel olarak önemli bulunmuştur. Çeşitlerin yetişme süresi de yağ oranı üzerine etkili olmaktadır. Erkenci çeşitlerin yağ oranı, geççi çeşitlere göre daha düşük olmaktadır. NC-7 çeşidi, Sultan çeşidine göre daha erkencidir. Ayrıca, çeşitlerin farklı genetik özelliğe sahip olmaları da, yağ oranı üzerine etkili olmaktadır [27, 28, 29, 30, 24].

Tablo 5. Ana ürün koşullarında denemeye alınan farklı büyüme özelliğine sahip yerfıstığı çeşitlerinin, farklı bitki yoğunluğuna göre elde edilen iki yıllık ortalama yağ ve protein oranı değerleri ile EGF $(\% 5)$ 'e göre oluşan gruplar

\begin{tabular}{|c|c|c|c|c|c|c|}
\hline \multirow{3}{*}{$\begin{array}{c}\text { Bitki } \\
\text { Yoğunluğu (B) } \\
\left(\text { adet } \text { da }^{-1}\right)\end{array}$} & \multicolumn{3}{|c|}{ Yağ Oranı (\%) } & \multicolumn{3}{|c|}{ Protein Oranı $(\%)$} \\
\hline & \multicolumn{2}{|c|}{ Çeşitler (A) } & \multirow{2}{*}{$\begin{array}{l}\text { Ortalama } \\
\text { (B) }\end{array}$} & \multicolumn{2}{|c|}{ Çeşitler (A) } & \multirow{2}{*}{$\begin{array}{c}\text { Ortalama } \\
\text { (B) }\end{array}$} \\
\hline & SULTAN & NC-7 & & SULTAN & NC-7 & \\
\hline 21.052 & 45,99 & 44,15 & $45,07 \mathrm{D}$ & 26,44 & 27,94 & $27,19 \mathrm{~A}$ \\
\hline 19.047 & 46,10 & 44,21 & $45,16 \mathrm{D}$ & 26,24 & 27,89 & $27,07 \mathrm{~A}$ \\
\hline 14.000 & 46,53 & 44,58 & $45,56 \mathrm{C}$ & 25,93 & 27,73 & $26,83 \mathrm{~B}$ \\
\hline 12.666 & 46,65 & 44,68 & $45,66 \mathrm{BC}$ & 25,70 & 27,62 & $26,66 \mathrm{BC}$ \\
\hline 10.526 & 46,83 & 44,72 & $45,77 \mathrm{AB}$ & 25,51 & 27,52 & $26,52 \mathrm{C}$ \\
\hline 9.523 & 46,99 & 44,73 & $45,86 \mathrm{~A}$ & 25,25 & 26,88 & $26,06 \mathrm{D}$ \\
\hline Ortalama (A) & $46,51 \mathrm{~A}$ & $44,51 \mathrm{~B}$ & - & $25,84 \mathrm{~B}$ & $27,60 \mathrm{~A}$ & - \\
\hline EGF (\%5) Değerleri & \multicolumn{3}{|c|}{$\begin{array}{c}\mathrm{EGF}\left(\% 5_{\mathrm{C}}\right): 1,44 ; \quad \operatorname{EGF}\left(\% 5_{\mathrm{BS}}\right): 1,19 \\
\operatorname{EGF}\left(\% 5_{\mathrm{C} \times \mathrm{BS}}\right): \text { Ö.D. }\end{array}$} & \multicolumn{3}{|c|}{$\begin{array}{r}\operatorname{EGF}\left(\% 5_{C}\right): 1,89 ; \operatorname{EGF}\left(\% 5_{\mathrm{BS}}\right): 0,17 \\
\operatorname{EGF}\left(\% 5_{\mathrm{CxBS}}\right): O ̈ . D .\end{array}$} \\
\hline
\end{tabular}

Çift sıralı ekim yöntemine göre oluşturulan farklı bitki yoğunluklarına göre denemeye alınan yerfıstığı çeşitlerinin yă̆ oranı değerleri birbirlerinden önemli derecede farklılıklar göstermiştir. İki yıllık ortalama değerlere göre Sultan çeşidine ait yă̆ oranı değerleri, farklı bitki sıklığına göre \%45,99-46,99 arasında, NC-7 çeşidinde ise \%44,15-44,73 arasında değişim göstermiştir (Tablo 5). Her iki çeşit için de yağ oranı değerleri arasında istatistiksel olarak farklılıklar saptanmış olup, birim alandaki bitki sayısı azaldıkça, yağ oranı değerlerinde önemli oranda artış gözlenmiştir. İki yıllık ortalama değerlere göre, çeşit farkı gözetmeksizin, birim alandaki bitki yoğunluğuna göre yă̆ oranı değerleri \%45,07-45,86 arasında değişim göstermiştir. Çalışmada en yüksek yağ oranı \%45.86 ile 9.523 adet da ${ }^{1}$ bitki yoğunluğundan elde edilmiştir. Yağ oranı değerleri bakımından çeşit $\mathrm{x}$ ekim sıklığı arasındaki interaksiyon istatistiksel olarak önemsiz bulunmuştur. Yağ oranı bakımından elde edilen değerler; Onat ve ark. [10], Kurt ve ark. [13], Yousif ve Hussain [23] ve Kenetli ve Arığlu [31] tarafindan elde edilen bulgular ile de desteklenmektedir.

\subsection{Protein Oranı}

Denemeye alınan yerfıstığı çeşitlerinin protein oranı değerleri \%25,84-27,60 arasında değişim göstermiş olup, çeşitler arasındaki farklılık istatistiksel olarak önemli bulunmuştur (Tablo 5). Protein oranı değeri, NC-7 çeşidinde $(\% 27,60)$, Sultan çeşidine $(\% 25,84)$ göre daha yüksek olmuştur. Protein oranı bakımından meydana gelen bu farklılıklar, çeşitlerin genetik yapılarının farklı olmasından ileri gelmektedir. Yağ oranı ile protein oranı arasında olumsuz bir ilişki olduğu için, yağ oranı yüksek olan çeşitlerde protein oranı düşük olmuştur [32, 28, 29, 30,24].
Tablo 5'in incelenmesinden de görüleceği gibi, iki yıllık ortalama değerlere göre farklı bitki sıklığına göre Sultan çeşidine ait protein oranı değerleri, \%25,25-26,44 arasında, NC-7 çeşidinde ise \%26,88-27,94 arasında değişim göstermiştir. Çift sıralı ekim yöntemine göre oluşturulan farklı bitki sıklıkları arasında, her iki çeşit için de istatistiksel olarak önemli farklılıklar oluşmuştur. İki yıllık ortalama değerlere göre birim alandaki bitki sayısı arttıkça, protein içeriğinde de önemli oranda artışlar saptanmıştır. Sultan ve NC-7 çeşitlerinin ortalamasına göre, birim alandaki bitki sayısı 21.052 adet $\mathrm{da}^{-1}$ olduğunda protein oranı \%27,19 iken, bitki sayıs1 9.323 adet $\mathrm{da}^{-1}$, a düştüğünde protein oranı da \%26,07'ye gerilemiştir. Protein oranı değerleri bakımından Çeşit x Ekim sıklığı arasındaki interaksiyon istatistiksel olarak önemsiz bulunmuştur. Protein oranı bakımından elde edilen değerler bazı araştırıcıların bulguları ile de örtüşmektedir [10, 13, 31].

\subsection{Dekara Meyve Verimi}

Ana ürün koşullarında denemeye alınan farklı büyüme özelliğine sahip yerfıstığı çeşitlerinden, farklı bitki sıklıklarına göre elde edilen iki y1llık ortalama dekara meyve verimi değerleri ile EGF(\%5)'e göre oluşan gruplar ve interaksiyon değerleri Tablo 6'da verilmiştir. 
Tablo 6. Ana ürün koşullarında denemeye alınan farklı büyüme özelliğine sahip yerfıstığı çeşitlerinİn, farklı bitki yoğunluğuna göre elde edilen iki yıllık ortalama dekara meyve verimi değerleri ile EGF $(\% 5)$ 'e göre oluşan gruplar

\begin{tabular}{|c|c|c|c|}
\hline \multirow{2}{*}{$\begin{array}{c}\text { Bitki } \\
\text { Yoğunluğu (B) } \\
\text { (adet da }^{-1} \text { ) }\end{array}$} & \multicolumn{3}{|c|}{ Meyve Verimi (kg da ${ }^{-1}$ ) } \\
\cline { 2 - 4 } & SULTAN & NC-7 & \\
\hline $\mathbf{2 1 . 0 5 2}$ & $627,7 \mathrm{~b}$ & $444,2 \mathrm{~g}$ & $535,9 \mathrm{C}$ \\
\hline $\mathbf{1 9 . 0 4 7}$ & $545,5 \mathrm{~d}$ & $434,7 \mathrm{~g}$ & $490,1 \mathrm{D}$ \\
\hline $\mathbf{1 4 . 0 0 0}$ & $519,9 \mathrm{e}$ & $415,5 \mathrm{~h}$ & $467,7 \mathrm{E}$ \\
\hline $\mathbf{1 2 . 6 6 6}$ & $754,4 \mathrm{a}$ & $582,2 \mathrm{c}$ & $668,3 \mathrm{~A}$ \\
\hline $\mathbf{1 0 . 5 2 6}$ & $640,8 \mathrm{~b}$ & $519,7 \mathrm{e}$ & $580,3 \mathrm{~B}$ \\
\hline $\mathbf{9 . 5 2 3}$ & $580,1 \mathrm{c}$ & $467,6 \mathrm{f}$ & $523,8 \mathrm{C}$ \\
\hline Ortalama (A) & $611,4 \mathrm{~A}$ & $477,3 \mathrm{~B}$ & - \\
\hline EGF (\%5) Değerleri & EGF(\% $\left.5_{\mathrm{A}}\right): 18,42 ; \quad$ EGF(\% $\left.\% 5_{\mathrm{B}}\right): 12,68$ \\
\hline
\end{tabular}

Tablo 6'nın incelenmesinden de görüleceği gibi meyve verimi değerleri bakımından çeşitler ve ekim sıklıkları arasındaki farkl1lıklar istatistiksel olarak önemli bulunmuştur. Çift sıralı ekim yöntemine göre düzenlenen farklı bitki sıklığına göre oluşturulan parsellere yapılan ekimlerde, dekara ortalama meyve verimi değeri Sultan çeşidinde $611,4 \mathrm{~kg} \mathrm{da}^{-1}$ iken, NC-7 çeşidinde $477,3 \mathrm{~kg}$ $\mathrm{da}^{-1}$ olmuştur. İki yıllık ortalama değerlere göre, Sultan çeşidinden elde edilen dekara meyve verimi $134,1 \mathrm{~kg}$ da ${ }^{1}$ daha yüksek bulunmuştur. Sultan çeşidi, meyve verimi bakımından, NC-7 çeşidine göre daha üstün potansiyele sahiptir. Çeşitler arasında meydana gelen bu farklılık çeşitlerin verim potansiyeli bakımından (bitki başına meyve sayısı ve ağırlığı, 100 tohum ağırlığı gibi özellikler bakımından) farklı genetik yapıya sahip olmalarından kaynaklanmaktadır $[6,9,24,33]$.

Çalışmada, dekara meyve verimi değerleri bakımından, çift sıralı ekim yöntemine göre oluşturulan her iki çeşide ait bitki sıklıkları arasında, istatistiksel olarak önemli farklılıklar saptanmıştır. İki yıllık ortalama değerlere göre, dekara meyve verimi Sultan çeşidinde 519,9-754,4 $\mathrm{kg} \mathrm{da}^{-1}$ arasında, NC-7 çeşidinde ise 415,5-582,2 $\mathrm{kg} \mathrm{da}^{-1}$ arasında değişim göstermiştir (Tablo 6). İki yıllık ortalama değerlere göre dekara en yüksek meyve verimi; her iki çeşitte de 80-25-80 ekim yöntemine göre sira üzeri mesafesi $15 \mathrm{~cm}$ (12.666 adet $\mathrm{da}^{-1}$ bitki sıklığı) olacak şekilde ekim yapılan parsellerden elde edilmiştir. Tablo 6'nın incelenmesinden de görüleceği gibi, iki yıllık ortalamaya göre 12.666 adet da $^{-1}$ ekim sıklığında elde edilen ortalama meyve verim değeri Sultan çeşidinde $754,4 \mathrm{~kg} \mathrm{da}^{-1}$ ve NC-7 çeşidinde ise $582,2 \mathrm{~kg}$ $\mathrm{da}^{-1}$ olmuştur. Dekara en düşük meyve verimi ise her iki çeşitte de 70-25-70x15 cm olacak şekilde çift sıralı ekim yöntemine göre, dekara 14.000 adet bitki ${ }^{-1}$ bulunacak şekilde ekim yapılan parsellerden elde edilmiştir $(467,7$ $\mathrm{kg} \mathrm{da}^{-1}$ ). İki yıllık ortalama değerlere göre dekara en yüksek verim, birim alanda 12.666 adet da $^{-1}(668,3 \mathrm{~kg}$ $\left.\mathrm{da}^{-1}\right)$ ve 10.526 adet da $^{-1}\left(580,3 \mathrm{~kg} \mathrm{da}^{-1}\right)$ bitki bulunacak şekilde yapılan çift sıralı ekimlerden elde edilmiştir (Tablo 6). Ayn anlaşılacağı üzere, çift sıralı ekim yöntemindeki kadar, sıra üzeri mesafesi de, birim alandan elde edilen verim üzerine etkili olmaktadır. Ancak, bu durum çeşitlere göre farkl11ık göstermemektedir. Bu çalı̧̧mada, dekara meyve verimi bakımından elde edilen değerler, bazı araştırıcılar tarafından farklı bölgelerde yapılan araştırma bulguları ile de desteklenmektedir $[5,8,9,10,13,16,21-23,34]$.

\section{SONUÇ}

Elde edilen iki yıllık değerlere göre, incelenen özellikler bakımından çeşitler ve ekim sıklıkları arasında önemli farklılıkların olduğu görülmüştür. Yerfıstığı tarımında uygulanan çift sıralı ekim yönteminin verim üzerine etkili olduğu, ancak, bu ekim yönteminde uygulanan sıra arası ve sıra üzeri uzaklığının doğru olarak belirlenmesi gerekmektedir. Elde edilen sonuçlara göre, çeşitlerin büyüme özelliği, incelenen özellikler bakımından etkili olmadığı görülmüştür. Ana ürün yerfıstığı tarımında, çift sıralı ekim yöntemine göre dekara en yüksek verim, her iki çeşitten de 80-25-80x15 cm olarak uygulanan ekim yöntemindeki bitki sıklığına sahip parsellerden elde edilmiştir. Buna göre elde edilen verim değerleri Sultan çeşidinde $754,4 \mathrm{~kg} \mathrm{da}^{-1}$ ve NC-7 çeşidinde ise $582,2 \mathrm{~kg}$ $\mathrm{da}^{-1}$ olarak gerçekleşmiştir.

\section{KAYNAKLAR}

[1] Arıoğlu H.H. Yağ Bitkileri Yetiştirme ve Islahı, Ç.Ü. Ziraat Fakültesi Ders Kitapları Ç.Ü. Ziraat Fakültesi Ofset Atölyesi, Yayın No: A-70; 2014.

[2] Food and Agriculture Organization of The United Nations (FAO). İstatistikler, http://www.fao.org/statistics/ databases/en/ Erişim tarihi: 10.02 .2020 .

[3] Türkiye İstatistik Kurumu (TUIKK). Konularına Göre İstatistikler, $\quad$ https://web.tuik.gov.tr/tr/ classificationcategories/. Erişim tarihi: 10.02.2020.

[4] Morla FD, Giayetto O, Fernandez EM, Cerioni GA, Cerliani C. Plant density and peanut crop yield (Arachis hypogaea L.) in the peanut growing region of Cordoba (Argentina). Peanut Science. 2018;45(2):82-86.

[5] Zhao C, Shao C, Yang Z, Wang Y, Zhang X, Wang M, Mc Giffen ME. Effect of planting density on pod development and yield of peanut under the pattern of precision planted peanuts. Legume Research. 2017;40(5):901-905.

[6] Lanier JE, Jordan DL, Spears JF, Wells R, Johnson PD, Barnes JS, Hurt CA, Brandenburg RL, Bailey JE. Peanut response to planting pattern, row spacing and irrigation. Agronomy journal. 2004;96(1):10661072.

[7] Kiniry JR, Simpson CE, Schubert AM, Reed JD. Peanut leaf area index, light interception, radiation use efficiency and harvest index at three sites in Texas. Field Crop Research. 2005;91(1):297-306.

[8] Rasekh H, Asgharı J, Safaızadeh MN, Zakerınejad R. Effect of planting pattern and plant density on physiological characteristics and yield of peanut in İan. Research Journal of Biological Sciences. 2010;5(8):542-547.

[9] Konlan S, Sarkodie-Addo J, Asare E, Kombiok MJ. Groundnut (Arachis hypogaea L.) varietal response to spacing in the Guinea Savana agro-ecological zone of Ghana: Growth and yield. African Journal of Agricultural Research. 2013;8(22):2769-2777. 
[10] Onat B, Bakal H, Güllüoğlu L, Arığlu H. The effects of row spacing and plant density on yield and yield components of peanut grown as a double cropped in Mediterranean environment in Turkey. Turkish Journal of Field Crops. 2017;22(1):71-80.

[11] Tarimo AJP, Blarney FP. Effect of plant population density and cultivar on growth, yield and yield components in groundnut (Arachis hypogaea L.). South African Journal of Plant and Soil. 1999;16(2):74-78.

[12] Kadiroğlu A. Yerfıstığı (Arachis hypogaea L.) yetiştiriciliğinde farklı çeşitler ve sıra üzeri mesafelere göre tek ve çift sıralı ekim yöntemlerinin karşılaştırılması. Süleyman Demirel Üniversitesi, Fen Bilimleri Enstitüsü. Doktora Tezi. Isparta. 2012.

[13] Kurt C, Bakal H, Güllüoğlu L, Arığlu H. The effect of twin row planting pattern and plant population on yield and yield components of peanut (Arachis hypogeal L.) at main crop planting in Cukurova region of Turkey. Turkish Journal of Field Crops. 2017;22(1):24-31.

[14] Mozingo RW. Skip-row planting and row pattern effects on Virginia-type peanut cultivars. Agronomy Journal. 1984;76(1):660-662.

[15] Mozingo RW, Swann CW. Response of VA98R peanut twin versus single row planting patterns. Proc. Am. Peanut Res. Educ. Soc. 2000;32:43.

[16] Sconyers LE, Brenneman TB, Stevenson, K.L. Effect of row paterrn, seeding rate, and inaculation date on fungicide efficacy and development of peanut stem rot. Plant Disease. 2007;91(3):273278.

[17] Krik KR, Massey HF, Monfort WS, Thomas J, Jordan B, Schmidt WB. Single row vs. twin row digging losses for two Virginia type peanut varieties. An ASABE Meeting Presantation. 2013;13(1):620-657.

[18] Güllüoğlu L, Bakal H, Onat B, Kurt C, Arığlu H. The effect of harvesting dates on yield and some agronomic and quality characteristics of peanut grown in Mediterranean region (Turkey) Turkish Journal of Field Crops. 2016;21(2):224-232.

[19] Virk AS, Kaul JN, Bhangoo BS, Singh A. Influence of planting techniques and plant population on biology and pod productivity of summer groundnut varieties. Oil Crops Research. 2005;6(1):173-174.

[20] Abdullah T, Rahmanna AA, Hardaningsih S, Rozi F. Increasing groundnut yield on dry land Alfisols in Indonesia. Journal of Semi-arid Tropics Agricultural Research. 2007;5(1):84-86.

[21] Ahmad N, Rahim M, Khan U. Evaluation of different varieties, seed rates and row spacing of groundnut, planted under agro-ecological conditions of Malakand division. Journal of Agronomy. 2007;6(2):385-387.

[22] Awal MA, Aktar L. Effect of row spacing on the growth and yield of peanut (Arachis hypogaea L.) stands. International Journal of Agriculture Forestry and Fisheries. 2015;3(1):7-11.

[23] Yousif DP, Hussain A. Effect of genotype and plant density on growth characteristics and yield of peanut (Arachis hypogaea L.) in central region of
Iraq. Agricultural Research and Technology Journal. 2019;19(3):101-106.

[24] Güllüoğlu L, Bakal H, Onat B, Kurt C, Arıoğlu H. Comparison of agronomic and quality characteristics of some peanut varieties grown as main and double crop in Mediterranean region. Turkish Journal of Field Crops. 2017;22(2):166177.

[25] Kvien SS, Bergmark CL. Growth and development of the Florunner peanut cultivars as influenced by population, planting date and water availability. Peanut Sci. 1987;14(1):11-16.

[26] Arıoğlu E, Arığlu H. Ana ürün yerfıstığ yetiştiriciliğinde bitki yoğunluğunun verim ve bazı tarımsal özelliklere etkisi. Türkiye VII. Tarla Bitkileri Kongresi Erzurum. Bildiriler Kitab1-II. 2007; s 557-561.

[27] Hassan F, Ahmed M. Oil and fatty acid composition of peanut cultivars grown in Pakistan. Pakistan journal of Botany. 2012;44(2):627-630.

[28] Chowdhury FN, Hossain D, Hosen M, Rahman S. Comparative study on chemical composition of five varieties of groundnut (Arachis hypogaea L.). World Journal of Agricultural Science. 2015;11(5):247-254.

[29] Escobedo RM, Luna PH, Torres ICJ, Moreno AO, Ramirez MCR. Physicochemical properties and fatty acid profile of eight peanut varieties grown in Mexico. Journal of Food. 2015;13(2):300-304.

[30] Mahatma MK, Thawait LK, Bishi SK, Khatediye N, Rathnakumar AL, Lalwani HB, Misra JB. Nutritional composition and antioxidant activity of Spanish and Virginia groundnut (Arachis hypogaea L.) a comparative study. J. Food Sci. Technology. 2016;53(5):2279-2286.

[31] Kenetli A, Arığlu H. Ana ürün koşullarında yetiştirilen farklı büyüme özelliğine sahip yerfistığı çeşitlerinde, sıra üzeri uzaklığının verim ve bazı tarımsal özelliklere etkisinin belirlenmesi. Uluslararası 5 Ocak Uygulamalı Bilimler Kongresi Adana 2020. Bildiriler Kitab1. 2020;s. 64-74.

[32] Dwivedi SL, Nigam SN, Nageswara RC, Singh U, Rao KVS. Effect of drought on oil, fatty acids and protein contents of groundnut (Arachis hypogaea L.) seeds. Field Crops research. 1996;48:125-133.

[33] Balkom KS, Arriaga FJ, Balkom KB, Boykin DL. Single and Twin-row peanut production within narrow and wide strip tillage systems. Agronomy Journal. 2010;102(2):507-512 .

[34] Shiyam JO. Growth and yield response of groundnut (Arachis hypogaea L.) to plant densities and phosphorus on an ultisol in Southeastern Nigeria. Libyan Agriculture research Center Journal International. 2010;1(4):211-214 